\title{
Antioxidant Effect of Nigella Sativa Seed Powder and Thymoquinone in Normal and Sterptozotocine Induced Diabetic Albino Rats
}

\author{
Shaik Hussain Saheb *1, Desai SD ${ }^{2}$, Kusal K Das ${ }^{3}$, Haseena $\mathbf{S}^{4}$.
}

${ }^{* 1}$ Ph.D Scholar, Department of Anatomy, Shri B M Patil M edical College Hospital \& Research Centre, Bijapur and Assistant Professor in Anatomy, JJM Medical College, Davangere, Karnataka, India.

2 Principal \& Professor of Anatomy, Shridevi Institute of Medical Sciences and Research Hospital, Tumkur, Karnataka, India.

${ }^{3}$ Professor, Department of Physiology, Shri B M Patil M edical College Hospital \& Research Centre, Bijapur, Karnataka, India.

${ }^{4}$ Ph.D Scholar, Department of Physiology, Shri B M Patil Medical College Hospital \& Research Centre, Bijapur and Lecturer in Physiology, JJM M edical College, Davangere, Karnataka, India.

\section{ABSTRACT}

\begin{abstract}
Introduction: Malondialdehyde (MDA) cause toxic stress in cells and form covalent protein and its used as a biomarker to measure the level of oxidative stress. There is opposite mechanism which control the flux of reactive oxygen species (ROS) called as antioxidant system, which includes both enzymatic andnon-enzymatic components. The important enzyme of this system is superoxide dismutase (SOD). The black cumin or Nigella Sativaseeds are used in traditional medicine of different countries. Thymoquinone is major bioactive component of nigellasativa seed and it is the cause of therapeutic property of Nigella sativa seed. The present study is conducted to see the effect of Nigella Sativa seed powder and Thymoquinone on Serum M DA and SOD levels in normal and Streptozotocine Induced Diabetic Rats.

Materials and M ethods: 36 rats were selected for this study and divided in to 6 groups each contains 6 rats, one group served as normal control, one group served as normal rats received the nigella sativa seed powder(300mg/ $\mathrm{Kg} \mathrm{BW})$, one groups served as normal rats received the Thymoquinone $(4 \mathrm{mg} / \mathrm{kg} \mathrm{BW})$, one group served as Streptozotocine $(50 \mathrm{mg} / \mathrm{kg} \mathrm{BW})$ induced diabetic control rats, one group served as diabetic rats received the nigella sativa seed powder $(300 \mathrm{mg} / \mathrm{Kg} \mathrm{BW})$ and one groups served as diabetic rats received the Thymoquinone(4mg/kg BW).

Results: There is no change in MDA and SOD levels in normal rats treated with nigella sativa seed powder and thymoqinone. The levels of MDA are increased significantly in diabetic rats compared with normal rats, when the diabetic groups treated with nigella sativa seed powder and thymoqinone the MDA levels are decreased significantly $(p \varangle 0.05)$. The levels of SOD are decreased significantly in diabetic rats compared with normal rats, when the diabetic groups treated with nigella sativa seed powder and thymoqinone the SOD levels are increased significantly.
\end{abstract}

Conclusion: The results of these study concluding that nigella sativa seed powder and thymoquinone has having antioxidant effect in diabetic rats which lowering the M DA levels and increasing the SOD levels in streptozotocine induced diabetic rats.

KEY WORDS: M DA, SOD, Nigella Sativa seed, Antioxidant. Thymoquinone.

Address for correspondence: Shaik Hussain Saheb, Assistant Professor in Anatomy, JJM M edical College, Davangere, Karnataka, India. M obile no.: +91-9242056660E-Mail: anatomyshs@ gmail.com

\begin{tabular}{|c|c|c|}
\hline \multicolumn{3}{|c|}{ Online Access and Article Informtaion } \\
\hline \multirow{2}{*}{$\begin{array}{c}\text { Quick Response code } \\
\text { Dol: } 10.16965 \text { ijims.2016.108 }\end{array}$} & \multicolumn{2}{|c|}{$\begin{array}{l}\text { International Journal of Integrative Medical Sciences } \\
\qquad \text { www.imedsciences.com }\end{array}$} \\
\hline & $\begin{array}{l}\text { Received: 04-03-2016 } \\
\text { Reviewed: 04-03-2016 }\end{array}$ & $\begin{array}{l}\text { Accepted: 19-03-2016 } \\
\text { Published: 31-03-2016 }\end{array}$ \\
\hline Source of Funding: Self & \multicolumn{2}{|c|}{ Conflicts of interest: None } \\
\hline
\end{tabular}




\section{INTRODUCTION}

The one the most important and frequently using seed in traditional medicine many parts of the world, particularly in the Middle-East and FarEast countries, for the prevention and treatment of a large number of diseases is nigella sativa seed also popularly known as Black Seed. The active components of nigella sativa seeds having the great pharmacological properties, including, antidiabetic, antioxidant, anti-inflammatory, analgesic, antipyretic, antiasthmatic, antihypertensive, antimicrobial and antineo-plastic [1,2]. The holistic medicinal property of nigella sativa seed is due to its major bioactive component thymoquinone [3]. Thymoquinone got its medicinal property due to its nature of pharmacologically active quinone, which possesses several properties including analgesic and anti-inflammatory actions, protection against chemical induced carcinogenesis and the inhibition of eicosanoids generation $[4,5]$. Oxidative stress is leads to oxidative damage of cell which can measure by antioxidant status.

Accordingly, there has been increasing interest regarding the role and use of natural antioxidants as a means of preventing oxidative damage in diabetes due to high oxidative stress. Nigella Sativa contains _30 w/w of a fixed oil, and $0.40-0.45 \mathrm{w} / \mathrm{w}$ of a volatile oil. The volatile oil has been shown to contain $18.4-24 \%$ thymoquinone and $46 \%$ monoterpenes, such as p-cymene and a-pinene [6]. Antioxidants (e.g., vitamins $C$ and $E$, enzyme superoxide dismutase (SOD), catalase (CAT), and glutathione peroxidase (GSHPx)) have been shown to protect cells against lipid peroxidation, the initial step in many pathological processes [7]. Reduced antioxidant levels as a result of increased free radical production in experimental diabetes have been reported by many authors [8]. The present study was undertaken to determine the M DA and SOD levels in Streptozotocine induced diabetic albino rats.

The major active constituent of NigellaSativa seed is Thymoquinone, it is a pharmacologically active quinone, it has possesses several properties including analgesic and antiinflammatory actions, protection against chemical induced carcinogenesis and the inhibi- -tion of eicosanoids generation $[9,10]$. In previous studies reported that thymoquinone prevents oxidative injury in hepatocytes induced by carbon tetrachloride or tert-butyl hydroperoxide in various in vitro and in vivo hepatotoxicity models, as well as acetic acid-induced colitis in rats. In previous studies it has been suggested that thymoquinone may act as an antioxidant agent and prevent the membrane lipid peroxidation in hepatocytes[11-13].

Type 2 diabetes is the most prevalent and serious metabolic disease all over the world, and its hallmarks are pancreatic beta cell dysfunction and insulin resistance. Under diabetic conditions, chronic hyperglycaemia and subsequent augmentation of reactive oxygen species (ROS) deteriorate beta cell function and increase insulin resistance which leads to the aggravation of type 2 diabetes. In addition, chronic hyperglycaemia and ROSare also involved in the development of atherosclerosis which is often observed under diabetic conditions. Taken together, it is likely that ROS play an important role in the development of type 2 diabetes and atherosclerosis. It has been shown that ROS are produced in various tissues under diabetic conditions $[14,15]$. There are several sources of ROS in cells such as the nonenzymatic glycosylation reaction [16], the electron transport chain in mitochondria [17], and membrane-bound NADPH oxidase $[18,19]$. In diabetic animals, glycation reaction is observed in various tissues and organs, and various kinds of glycated proteins such as glycosylated haemoglobin, albumin, and lens crystalline are produced in a non-enzymatically manner through the glycation reaction. The reaction produces Schiff base, Amadori product, and finally advanced glycosylation end products (AGEs). During the process, ROS are also produced. The electron transport chain in mitochondria is also an important pathway to produce ROS. Under diabetic conditions, electron transport chain is activated, which leads to production of larger amounts of ROS. It has been shown that membrane-bound NADPH oxidase is also an important source of ROS.

The increased extra and intracellular glucose concentrations result in oxidative stress, which seems to be due mainly to increased production 
of reactive oxygen species (ROS) and free radicals with a sharp reduction in antioxidant body defences [20]. Free radicals are continuously produced during normal physiolo-gic processes and attack macromolecules including proteins, lipids, and DNA, so causing tissue injury. It has been widely accepted that oxidative stress plays a key role in the onset and development of diabetes complications, notably nephropathy [21]. Several mechanisms seem to be involved in the generation of oxidative stress in experimental animals and patients. These mechanisms include glucose autoxidation, peroxidation or glycation of proteins, lipids, and DNA. Oxidative stress can arise from a number of different sources, whether disease state or lifestyle, including episodes of ketosis, sleep restriction, and excessive nutrient intake [22]. In the past two decades, it has become increasingly clear that oxidative stress plays a major role in the pathogenesis of a number of human diseases such as atherosclerosis, chronic renal failure, ischemia/reperfusion injury, neurodegenerative diseases, hypertension, cancer and diabetes mellitus[23-27]. The present study is focused to find out nigella sativa seed powder and thymoquinone effect on MDA and SOD in normal and streptozotocine induced diabetic rats. The aim of present study is to observe the antioxidant property of Nigella Sativa seed and its major bioactive component Thymoquinone in normal and streptozotocine induced diabetic rats.

\section{MATERIALS AND METHODS}

Study design: This work is conducted as part of Ph.D work under Department of Anatomy, Shri BM patil Medical College, BLDE University, Bijapur. University ethical committee and Inistitution Animal Ethical committee are approved the work according to CPCSEA Rules (BLDEU/Dept of pharmacology 602/13). The 36 rats were selected for this study and divided in to 6 groups each contains 6 rats, 3 groups are normal rats out of that one group served as normal control rats, one group was treated with nigella sativa seed powder $(300 \mathrm{mg} / \mathrm{Kg}$ BW weight), one group was treated with thymoquinone $(4 \mathrm{mg} / \mathrm{kg}$ body weight). Other three groups were induced diabetic by single rapid intraperitoneal injection of streptozotocine (50mg/ kg body weight) streptozotocine out of that one group served as diabetic control, one group as diabetic treated with nigella sativa and one group served as diabetic rats treated with thymoquinone, at the end of $45^{\text {th }}$ day blood was collated and measured MDA (Nadiger et al method) [28] and SOD (M arklund and M arklund) [29].

Plant material: Nigella sativa seeds were purchased from Safa honey $\&$ Co, Bangalore and grinded in to fine powder [27] with piston and mortal with help of Bapuji pharmacy college, Davangere. Nigella sativa pow der administrated orally according to study of M. M urugesan [30].

Thymoquinone: Thymoquinone purchaged from Sigma-Aldrich, Bangalore and administrated to rats through intraperitoneal injections $(4 \mathrm{mg} /$ body Kg weight).

Streptozotocine-Induced diabetis: The rats were given Streptozotocine intraperitoneal injection 50mg/BW, Streptozotocine dissolved in icecold citrate buffer(PH 4.5). The diabetes was confirmed by measuring glucose by Code free Glucometer, the glucose level above $250 \mathrm{mg} / \mathrm{dl}$ considered as diabetes, glucose levels were checked at every day morning.

\section{RESULTS}

M DA ( $\mathrm{nmol} / \mathrm{ml}$ ) level of Normal Control rats was $6.64 \pm 0.99$, normal rat treated with Thymoquinone rats was $6.45 \pm 0.73$, diabetic rat treated with nigella sativa rats was $6.51 \pm 1.11$. Diabetic control rats was $12.70 \pm 1.54$, diabetic rat treated with Thymoquinone rats was $6.98 \pm 1.60$, diabetic rat treated with nigella sativa rats was $7.39 \pm 1.05$. SOD $(\mathrm{U} / \mathrm{ml})$ level of Normal

Table 1: One Way ANOVA Results of MDA, SOD.

\begin{tabular}{|c|c|c|c|c|c|c|c|c|}
\hline \multirow{2}{*}{ Parameter } & \multicolumn{9}{|c|}{ Groups } & \begin{tabular}{c} 
Normal Rats - \\
\cline { 2 - 9 }
\end{tabular} & Control & $\begin{array}{c}\text { Nigella Sativa Seed } \\
\text { Powder }\end{array}$ & $\begin{array}{c}\text { Normal Rats - } \\
\text { Thymoquinone }\end{array}$ & $\begin{array}{c}\text { Diabetic Rats - } \\
\text { Control }\end{array}$ & $\begin{array}{c}\text { Diabetic Rats - } \\
\text { Nigella sativa seed } \\
\text { powder }\end{array}$ & $\begin{array}{c}\text { Diabetic - } \\
\text { Thymoquinone }\end{array}$ & $\mathbf{F}$ & $\mathbf{P}$ \\
\hline $\begin{array}{c}\mathbf{M D A} \\
(\mathbf{n m o l} / \mathbf{m l})\end{array}$ & $6.63 \pm 0.99$ & $6.51 \pm 1.11$ & $6.45 \pm 0.73$ & $12.70 \pm 1.53$ & $7.39 \pm 1.04$ & $6.98 \pm 1.60$ & 24.276 & 0 \\
\hline $\begin{array}{c}\mathbf{S O D} \\
(\mathbf{U} / \mathrm{ml})\end{array}$ & $4.91 \pm 0.71$ & $5.01 \pm 0.71$ & $5.11 \pm 0.64$ & $1.57 \pm 0.27$ & $3.70 \pm 0.72$ & $4.14 \pm 1.14$ & 19.521 & 0 \\
\hline
\end{tabular}


Control rats was $4.91+0.71$, normal rat treated with Thymoquinone rats was $5.11+0.64$, diabetic rat treated with nigella sativa rats was 5.01+0.71. Diabetic control rats was 1.57+0.27, diabetic rat treated with Thymoquinone rats was $4.14 \pm 1.14$, diabetic rat treated with nigella sativa rats was $3.70+0.72$ (Table 1 ).

Graph 1: Vitamin MDA (nmol/ml).

$\operatorname{MDA}(\mathrm{nmol} / \mathrm{ml})$

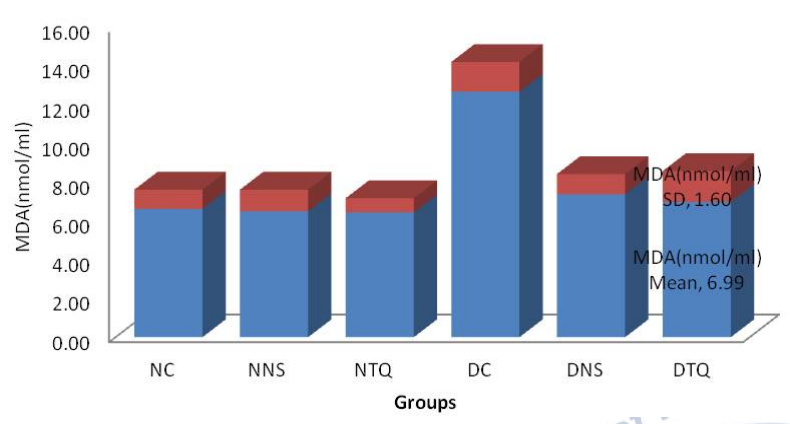

NC- Normal Control Rats, NNS- Normal rats treated with NIgella Sativa, NTQ- Normal rats Treated with Thymoquinone, DC- Diabetic Control Rats, DNS- Diabetic rats treated with NIgella Sativa, DTQDiabetic rats Treated with Thymoquinone.

Graph 2: Vitamin SOD $(\mathrm{U} / \mathrm{ml})$. $\mathrm{SOD}(\mathrm{U} / \mathrm{ml})$

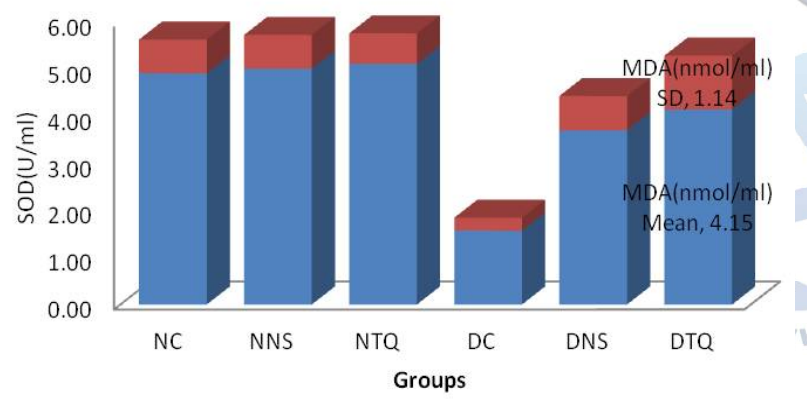

NC- Normal Control Rats, NNS- Normal rats treated with NIgella Sativa, NTQ- Normal rats Treated with Thymoquinone, DC- Diabetic Control Rats, DNS- Diabetic rats treated with NIgella Sativa, DTQDiabetic rats Treated with Thymoquinone.

\section{DISCUSSION}

In present study M DA (nmol/ml) level of Normal Control rats was $6.64 \pm 0.99$, normal rat treated with Thymoquinone rats was $6.45 \pm 0.73$, diabetic rat treated with nigella sativa rats was $6.51 \pm 1.11$. Diabetic control rats were $12.70 \pm 1.54$, diabetic rat treated with Thymoquinone rats was $6.98 \pm 1.60$, diabetic rat treated with nigella sativa rats was 7.39+1.05. Abdelmeguid NE et al study also shown similar findings that MDA levels are increased in diabetic rats and after treated with Nigella sativa extract MDA levels are decreased [31]. In study of Edibe Sariciceka, et al. observed decreased levels of
MDA when treated with nigella sativa and thymoquinone [32]. In study of Yasin TULUCE also observed same results [33]. Kanter et al studied the effect of black seed on lipid peroxidation and antioxidant defense system and found that treatment with the volatile oil of Nigella sativa decreased blood M DA levels and increased the antioxidant defence system activity in carbon tetrachloride treated rats [34]. In present study SOD(U/ml) level of Normal Control rats was $4.91 \pm 0.71$, normal rat treated with Thymoquinone rats was $5.11 \pm 0.64$, diabetic rat treated with nigella sativa rats was $5.01 \pm 0.71$. Diabetic control rats was $1.57 \pm 0.27$, diabetic rat treated with Thymoquinone rats was $4.14 \pm 1.14$, diabetic rat treated with nigella sativa rats was 3.70 \pm 0.72 . Hanene J rah Harzallah et al study shows that after treated with thymoquinone and nigella sativa SOD levels [35]. In study of Nabila EAbdelmeguid et al found similar findings [36]. Our results are in agreement with studies of Tuncel $\mathrm{N}$ et al [37], Kanter M et al [38], A.A. Sayed [39], Bassem $Y$ et al [40], Dalia A. Hafez [41]. ROS are continuously produced during normal physiologic events, and removed by antioxidant defence mechanism. In pathological conditions, ROS are over produced and result in lipid peroxidation and oxidative damage. The imbalance between ROS and antioxidant defence mechanisms leads to oxidative modification in the cellular membrane or intracellular molecules [36]. The present study results are confirmed that Nigella sativa seed powder and thymoquinone may have antioxidant properties that will be useful for therapeutic purposes. The results of the present study indicate that the preventive effects of Nigella sativa seed and thymoquinone may be due to inhibition of lipid peroxidation as a result of its antioxidant nature.

\section{ACKNOWLEDGEM ENTS}

The authors are very thankful to Dr. B.M. Bannur, Prof \& HOD of Anatomy, Shri B M Patil Medical College Hospital \& Research Centre, Bijapur, Dr. Manjunath Alur, Principal, Dr Manjunath M Tembad, Prof \& HOD of Biochemistry, $\mathrm{Dr}$ Mavishettar GF, Prof \& HOD of Anatomy, JJM Medical College, Davangere and Dr Muralidhar P Shepur, Asst Professor of anatomy, GIMS, Gulbarga. 


\section{REFERENCES}

[1]. Padhye S, Banerjee S, Ahmad A, M ohammad R and Sarkar FH. From here to eternity the secret of Pharaohs: Therapeutic potential of black cumin seeds and beyond. Cancer Ther., 2008:495-510.

[2]. Randhawa M A and Alghamdi MS. Anticancer activity of Nigella sativa (Black seed) A Review. Am.J. Clin. Med. 2011;39(6):1075-1091.

[3]. Al-Ali A, Alkhawajah A, Randhawa MA and Shaikh NA. Oral and intraperitoneal LD50 of thymoquinone, an active principle of Nigella sativa, in mice and rats. J. Ayub M ed. Coll. 2008;20(2):2527.

[4]. Houghton PJ, Zarka R, De-Las-Heras B, Hoult JR. Fixed oil of Nigella sativa and derived thymoquinone inhibit Eicosanoid generation in leukocytes and membrane lipid peroxidation. Planta Med 1995; 61:33-36.

[5]. Hassan M, El-Dakhakhny M. Effect of some Nigella sativa constituents on chemical carcinogenesis in hamster cheek pouch. J Egypt Soci Pharmacol Exp Ther 1992;11:675-677.

[6]. El-Tahir KEH, Al-Harbi MMS, Ashour MM. The cardiovascular actions of the volatile oil of the black seed in rats: elucidation of the mechanism of action. Gen Pharmacol. 1993;24:1123-1131.

[7]. Bray TM, Bettger WJ. The physiological role of zinc as an antioxidant. Free Radic Biol Med. 1990;8:281-291.

[8]. Kanter M, M eral I, Dede S, Gunduz H, Cemek M, Ozbek H. Effects of Nigella sativa L. and Urtica dioica $L$. on lipid peroxidation, antioxidant enzyme systems and some liver enzymes in $\mathrm{CCl} 4$ - treated rats. J Vet Med A Physiol Pathol Clin Med. 2003;50:264-268.

[9]. Houghton PJ, Zarka R, De-Las-Heras B, HoultJR. Fixed oil of Nigella sativa and derived thymoquinone inhibit Eicosanoid generation in leukocytes and membrane lipid peroxidation. Planta Med 1995;61:33-36.

[10]. Hassan M, El-Dakhakhny M . Effect of some Nigella sativa constituents on chemical carcinogenesis in hamster cheek pouch. J Egypt Soci Pharmacol Exp Ther 1992;11:675-677

[11]. M ansour M A, Ginawi OT, El-Hadiyah T, El-Khatib AS, Al-Shabanah OA, Al-Sawaf HA. Effects of volatile oil constituents of Nigella sativa on carbon tetrachloride-induced hepatotoxicity in mice: evidence for antioxidant effects of thymoquinone. Res Commun M ol Pathol Pharmacol 2001;110: 239251.

[12]. Nagi M N, Alam K, Badary OA, Al-Shabaneh OA, AlSawaf HA, Al-Bekairi AM. Thymoquinone protects against carbontetra chloride hepatotoxicity in mice via an antioxidant mechanism. Biochem Mol Biol Int 1999;47:153-159.

[13]. M ansour M A, Nagi M N, El-Khatib AS, Al-Bekairi AM . Effects of thymoquinone on antioxidant enzyme activities, lipid peroxidation and DT-diaphorase in different tissues of mice: a possible mechanism of action. Cell Biochem Funct 2002;20:143-151.

[14]. J. W. Baynes and S. R. Thorpe, "Role of oxidative stress in diabetic complications: a new perspective on an old paradigm," Diabetes. 1999;48(1):1-9.

[15]. P. Dandona, K. Thusu, S. Cook, et al. Oxidative damage to DNA in diabetes mellitus. The Lancet. 1996;347(8999):444-445.

[16]. T. Sakurai and S. Tsuchiya. Superoxide production from nonenzymatically glycated protein. FEBS Letters. 1988;236(2):406-410.

[17].M. Brownlee. Biochemistry and molecular cell biology of diabetic complications. Nature 2011;414(6865):813-820.

[18]. D. Harrison, K. K. Griendling, U. Landmesser, B. Hornig, and $\mathrm{H}$. Drexler. Role of oxidative stress in atherosclerosis. The American Journal of Cardiology. 2003;91(3):7A-11A.

[19]. H. K. M. M ohazzab, P. M. Kaminski, and M. S. Wolin. NADH oxidoreductase is a major source of superoxide anion in bovine coronary artery endothelium. American Journal of Physiology, 1994;266(6): $\mathrm{H} 2568-\mathrm{H} 2572$.

[20].Hayoz, D.; Ziegler, T.; Brunner, H.R. and Ruiz, J. Diabetes mellitus and vascular lesions. Metabolism. 1998;47:16-19.

[21].Bonnefont, D.; Bastard, J.P.; Jaudon, M.C. and Dellattre, J. Consequences of diabetes status on the oxidant $D$ antioxidant balance. Diabetes M etab. 2000;26:163-76.

[22]. Rains, J.L. and S.K. Jain. Oxidative stress, insulin signaling, and diabetes. Free. Radic. Biol. Med. 2011;50:567-575.

[23].Mates JM, Perez-Gomez C, NunezDeCastro I. Antioxidant enzymes and human diseases. Clin Biochem 1999;32:595-603.

[24].Desai S D, Shaik Hussain Saheb, Kusal K Das, Haseena S. Effect of Thymoquinone on MDA and SOD levels in Sterptozotocine Induced Diabetis Albino Rats. J. Pharm. Sci. \& Res. 2015;7(4):206209.

[25].Desai S D, Shaik Hussain Saheb, Kusal K Das, Haseena S. Effect of Nigella Sativa Seed Powder on MDA and SOD levels in Sterptozotocine Induced Diabetis Albino Rats. J. Pharm. Sci. \& Res. 2015;7(4):523-526.

[26]. Haseena S, Manjunath Aithal, Kusal K Das, Shaik Hussain Saheb. Phytochemical Analysis of Nigella Sativa and it's effect on reproductive system. J. Pharm. Sci. \& Res. 2015;7(8):514-517.

[27].Desai S D, Shaik Hussain Saheb, Kusal K Das, Haseena S. Phytochemical Analysis of Nigella Sativa and it's Antidiabetic Effect. J. Pharm. Sci. \& Res. 2015;7(8):527-532.

[28]. Nadiger Ha, Marcus Sr, ChandrakalaMv, Kulkarni Dd. Malondialdehyde Levels In Different Organs Of Rats Subjected To Acute Alcohol Toxicity. Indian Journal of Clinical Biochemistry 1986;133-136.

[29]. Marklund, S., M arklund, G. Involvement of the superoxyde anion radical in the auto oxidation of pyrogallol and a convenient assay for superoxyde dismutase. Eur. J. Biochem. 1974;47:469-474. 
[30].M. Murugesan, M. Ragunath, T. Prabu, S. Nadanasabapathi, M. Sakthivel, V. M anju. Protective role of black cumin (Nigella sativa) on isoproterenol induced myocardial infarction in rats. International Journal of Pharmacology and Clinical Sciences. 2012;1(2 ):45-53.

[31]. Abdelmeguid NE, Fakhoury R, Kamal SM, AI Wafai RJ. Effects of Nigella sativa and thymoquinone on biochemical and subcellular changes in pancreatic â-cells of streptozotocin-induced diabetic rats. J Diabetes. 2010 Dec;2(4):256-66.

[32].Edibe Sariciceka, M ehmet Tarakcioglub, Vahap Saricicekc, Murat Taner Gulsend, M etin Karakoke, Yasemin Baltacif, Seyithan Taysib. Effect of Nigella sativa on experimental liver fibrosis. Biomedical Research 2014; 25 (1): 32-38.

[33]. Yasin TULUCE, Halil OZKOL, Bünyamin SOGUT, Ismail ÇELIK. Effects of igella sativa L. on Lipid Peroxidation and Reduced Glutathione Levels in Erythrocytes of Broiler Chickens. Cell M embranes And Free Radical Research. 2009;1;3-1.

[34].Kanter M, Coskun O, Budancamanak M. Hepatoprotective effects of Nigella sativa $L$ and Urtica dioica $L$ on lipid peroxidation, antioxidant enzyme systems and liver enzymes in carbon tetrachloride- treated rats. World. J. Gastroenterol. 2005;11(42):6684-8.

[35]. Hanene Jrah Harzallah, Rahma Grayaa, Wafa Kharoubi, Aya Maaloul, Mohamed Hammami, Touhami Mahjoub. Thymoquinone, the Nigella sativa Bioactive Compound, Prevents Circulatory Oxidative Stress Caused by 1,2Dimethylhydrazine in Erythrocyte during Colon Postinitiation Carcinogenesis. Oxidative Medicine and Cellular Longevity. 2012:1-6.
[36]. Nabila E Abdelmeguid, Rajaa Fakhoury, Salwa M Kamal, Rana J Al Wafai. Effects of Nigella sativa and thymoquinone on biochemical and subcellular changes in pancreatic â-cells of streptozotocininduced diabetic rats. J Diabetes 2010 Dec;2(4):25666.

[37]. Tuncel N, Erkasap N, Sahinturk V, Ak DD, Tuncel M. The protective effect of vasoactive intestinal peptide (VIP) on stress-induced gastric ulceration in rats. Ann N Y Acad Sci 1998; 865: 309-322.

[38]. Kanter M, Meral I, Dede S, Gunduz H, Cemek M, Ozbek H. Effects of Nigella sativa L. and Urtica dioica $L$. on lipid peroxidation, antioxidant enzyme systems and some liver enzymes in $\mathrm{CCl} 4$ - treated rats. J Vet Med A Physiol Pathol Clin Med. 2003;50:264-268.

[39]. A.A. Sayed. Thymoquinone and proanthocyanidin attenuation of diabetic nephropathy in rats. European Review for M edical and Pharmacological Sciences 2012;16: 808-815.

[40].Bassem Y. Sheikh, Ahmed M. Mohamadin. Thymoquinone a potential therapy for cerebral. Oxidative stress asian journal of natural \& Applied Sciences. 2012;1;2.

[41]. Dalia A. Hafez. Effects of Nigella sativa Oil and Thymoquinone on Renal Oxidative Stress and Apoptosis Rate in Streptozotocin-Diabetic Rats. Journal of American Science 2013;9(3).

\footnotetext{
How to cite this article:

Shaik Hussain Saheb, Desai SD, Kusal K Das, Haseena S. Antioxidant Effect of Nigella Sativa Seed Powder and Thymoquinone in Normal and Sterptozotocine Induced Diabetic Albino Rats. Int] Intg M ed Sci 2016;3(3):242247. Dol: $10.16965 /$ ijims.2016.108
} 